\title{
CASE StUdY: Animal bedding cost and somatic cell count across New England dairy farms: Relationship with bedding material, housing type, herd size, and management system
}

\author{
M. M. Smith, ${ }^{1}$ C. L. Simms, and J. D. Aber \\ Department of Natural Resources, University of New Hampshire, Durham 03824
}

\begin{abstract}
Research on bedding material for dairy farmers typically focuses on microbial growth and associations with SCC. With few exceptions, information on cost or why farmers select specific bedding materials is absent from the literature. This survey study of conventional and organic dairy farmers from the 6-state New England region addresses these gaps, by exploring the relationship between bedding material cost and producer-reported SCC with bedding selection, housing type, farm scale, and management system. Survey analysis of 129 New England dairy farmers showed that the primary bedding materials used by respondents from conventional farms were sawdust, sand, and wood shavings, whereas organic farmers predominantly used sawdust, hay, and sand. From 2003 to 2013 the real cost of bedding material for survey respondents increased by $70 \%$ for conventional dairy farmers $(\$ 85$ to $\$ 184 /$ cow per year) and $71 \%$ for organic dairy farmers ( $\$ 67$ to $\$ 145 /$ cow per year). Of the various bedding materials used by respondents, the cost of wood shavings was more costly than other bedding materials for both conventional and organic dairy farmers. Respondents using freestalls had lower bedding material costs than other housing types, especially those using bedded packs, which had the highest material costs for both management systems. For conventional and organic farms, bedding cost decreased as herd size increased. When analyzing producer-reported SCC, no trends were apparent with housing type, herd size, or management system. However, respondents using sawdust reported elevated SCC when compared with producers using other bedding materials.
\end{abstract}

Key words: animal bedding cost, somatic cell count, bedding material, housing type, management system

The authors declare no conflict of interest.

${ }^{1}$ Corresponding author: m.smith@unh.edu

\section{INTRODUCTION}

One of the crucial factors in maintaining a healthy dairy herd is having sanitary animal bedding. This is because of the frequency and duration of contact between the cow and bedding material. Dairy cows will often lie down 8 to $16 \mathrm{~h} / \mathrm{d}$ if given the opportunity (Tucker et al., 2009). Importantly, extended time spent standing or lying down on unsanitary bedding increases the risk of environmental mastitis (Hogan et al., 1989). With bedding being one of the primary sources of exposure to environmental mastitis pathogens (Ruegg, 2006), the management of this material is important in maintaining herd health and the economic vitality of the farm.

In the highly forested region of New England, bedding from mill waste (sawdust and planer shavings) has historically been the most common and inexpensive product. However, there has been a continual decrease in the number of mills operating regionally over the last few decades. This problem accelerated in 2005, due to the collapse in the new home construction market, and went further in 2007 to 2009, due to the recession (Woodall et al., 2012). Increased mill efficiency and modernization also reduced the amount of mill by-product available for bedding. The combination of these supply disruptions has increased regional bedding costs, forcing dairy farmers to pay more or find alternative bedding materials. Consequently, this survey study was developed to determine what the current state of bedding usage and cost are across the 6 New England states. The objectives of this study are to assess the following: (1) what bedding materials are New England dairy farmers using, and why; (2) what percentage of dairy farmers experienced increased bedding costs over the last decade, and how were those costs managed; (3) what is the current annual bedding material cost per cow; (4) does bedding material, housing system, farm scale, or management system relate to producer-reported SCC or bedding cost; and (5) is there interest in the on-farm production of animal bedding using a wood shaving machine as a potential cost-saving and revenue-generating alternative. 


\section{MATERIALS AND METHODS}

\section{Survey Tool and Questions}

The survey tool used for this study was a mailed questionnaire, followed by an online version sent via email to those not responding to the paper mailing (the survey appears in the Supplemental Material; https://doi. org/10.15232/pas.2016-01601). The questionnaire was developed over a 6-mo period, with assistance from experts in the field of dairy and natural resource management. Research questions and the cover letter for the questionnaire were pretested using a focus group of university dairy farm managers and researchers. Cognitive interviewing was used during the focus group, to understand how individuals were interpreting each question and whether the group was interpreting questions consistently. This same group was also asked to validate the content of the questionnaire as a whole, to ensure it accurately addressed the specific research questions being asked. The focus group was also asked to carefully analyze the content of the cover letter, which described the aim of the study, who was conducting it, how the information would be used, the respondent's rights as a human subject, assurance of their confidentiality, and informed consent (right to participate or not). Upon completion, the questionnaire was provided to the University of New Hampshire Institutional Review Board for the Protection of Human Subjects in Research (IRB), which approved the study under IRB exempt status. Following IRB approval, the refined questionnaire was pilot tested by a small sample of the target population (3 organic farmers and 2 conventional farmers) to determine the ease, quality, and time requirement of the questionnaire. This process led to the omission of 2 questions for a final questionnaire of 28 questions. The online version of the questionnaire was also pilot tested by 3 members of the research team to ensure all links worked and the visual presentation made sense.

For reference, the survey question regarding SCC asked dairy farmers to report the herd average SCC over the past year, whether those values were from DHIA or from the milk plant. These producer-reported SCC values were not cross-referenced with DHIA or milk plant records. However, Wenz et al. (2007) conducted a questionnaire with producer-reported SCC, where a subset of the population was cross-referenced, and found that most producers across the 21 surveyed states did not underestimate SCC and that the producer-reported SCC was an accurate representation.

\section{Sample Size and Selection}

The target population for this study was conventional and organic dairy farm managers with active operations in the New England region. The initial goal was to obtain addresses for the entire population of regional dairy farmers (2,207 conventional and 250 organic; USDA, 2012, 2014). However, addresses for the entire population of conven- tional or organic dairy farmers were not publicly available. As such, an exploratory or case study approach was used, with purposive nonrandom sampling to develop the survey sample.

Addresses for conventional dairy farmers (both physical and email) used to develop the sample were obtained through state and national online directories. The primary directories used to obtain addresses were the New England States Holstein Association (Wells River, VT), American Jersey Cattle Association (Reynoldsburg, OH), US Ayrshire Breeders' Association (Columbus, $\mathrm{OH}$ ), and the American Guernsey Association (Columbus, OH). Participants for dairy farms using organic management were obtained from Organic Valley (La Farge, WI) and Moo Milk (Augusta, ME), who mailed questionnaires to their constituents on behalf of the research team, to maintain the privacy of their constituents.

\section{Questionnaire Mailings}

Questionnaires were sent by first class mail on March 17, 2014, to 395 conventional dairy farmers (18\% of the regional population) and 212 organic dairy farmers ( $85 \%$ of the regional population). A deliberate, late-winter mailing was selected to increase the response rate, because spring, summer, and fall are typically busier times of the year for dairy farmers. On May 9, 2014, the online version of the questionnaire was sent to dairy farm managers who did not respond to the mailed questionnaire. Farm managers were contacted by email with a link to the questionnaire, which was developed in SurveyMonkey (San Mateo, CA). One week following the first email, a reminder email was sent with a link to the questionnaire to those who had not responded to the first request. Only 35 dairy farmers were contacted using the online questionnaire, due to a lack of publicly available email addresses.

It is important to note that surveys were sent to all the dairy farmers compiled in our database. This was a deliberate decision and was based on reducing the issue of having a low response rate within the various study subgroups. More specifically, it was hypothesized that there would be a wide variation in responses based on the combination of management system, bedding material selection, housing type, and farm scale. With such a wide range of possible combinations across farms, it was decided that using all the contacts would reduce the risk of having small samples sizes within groups, which would mask potential trends. Furthermore, because analyses were descriptive and split by management system, there was not a concern regarding sending a greater proportion of the organic dairy industry questionnaires than those using conventional management.

\section{Data Analysis}

Raw data from both the mailed and online questionnaires were compiled in Microsoft Excel. Data were entered by one member of the research team, with every 
entry being verified by a second member to remove any type of response error. Missing data from questionnaires were dealt with on an individual question basis, where that particular respondents' results for that one question were omitted from data analysis.

Data regarding dairy farmers' top 5 farming expenses were analyzed using a scoring system, to give weight to the number of responses by rank corresponding to that expense. The following scoring system was used to determine which expenses were greatest for the sample population: rank 1 (10 points), rank 2 (8 points), rank 3 (6 points), rank 4 ( 4 points), rank 5 (2 points). By way of example, if the top 5 expenses for respondent 1 were feed, labor, fuel, bedding, and repairs, and respondent 2 reported labor, feed, fuel, bedding, and repairs, the ranking system would attribute 18, 18, 12, 8, and 4 points for feed, labor, fuel, bedding, and repairs, respectively.

Response rate was calculated 1 mo following the last email reminder to complete the online questionnaire. The response rate was adjusted from the original sample population of 607 to reflect questionnaires sent back in the mail due to a wrong address, a farm operation no longer in business, or questionnaires that were incomplete to the point that any form of data analysis could not be conducted.

Because the pool of respondents was generated from purposeful nonrandom sampling, due to the unavailability of addresses for the entire target population, a descriptive statistical approach was used. This involved measures of central tendency (mean, median, and mode) and variability (standard deviation), and the measures were conducted using JMP Pro 13 (SAS Institute Inc., Cary, NC). Descriptive statistics were used to assess whether trends existed for the case study farms for producer-reported SCC and bedding material cost per cow versus bedding material selection, housing type, farm scale, and management system. The following 8 relationships were analyzed: SCC as the dependent variable against (1) bedding material selection, (2) housing type, (3) farm size, (4) management system; additionally, bedding cost per cow was tested as the dependent variable against (5) bedding material selection, (6) housing type, (7) farm size, and (8) management system. Importantly, all analyses are meant only to summarize the data and trends for the case study farms and not to make inferences on a larger population, due to the sampling method.

\section{Nonresponse Bias}

The bias occurring from nonresponse, where survey respondent answers differ from nonrespondents, was addressed before and after the mailing of the questionnaire. Nonresponse bias was considered from the onset of the study by using components from the tailored design method (Dillman, 2000). The specific components that were used were as follows: (1) create a short respondent-friendly questionnaire developed with industry experts, (2) pretest the questionnaire multiple times, (3) include a return envelope with a first class stamp, (4) contact respondents multiple times over a several-month period through 2 modes of contact (mail and email), (5) provide contact information (phone and email) for the lead researcher in the cover letter, (6) describe how results of the questionnaire could indirectly benefit the respondent financially, (7) provide a description of university sponsorship (University of New Hampshire and University of Vermont), and (8) provide a token of appreciation (free copy of finished survey report). Nonresponse error after the questionnaire was considered by using a modified version of the comparison of demographic and socioeconomic difference method (Sivo et al., 2006), where farmer age, gender, and working experience were compared with the target population. Demographics (farmer age and gender), along with farm characteristics (number of head in the dairy herd and farm acreage) were compared with 2012 USDA Census of Agriculture data to determine whether a similar distribution existed between the research study and that of the agricultural census (USDA, 2012).

\section{RESULTS AND DISCUSSION}

\section{Response Rate and Survey Demographics}

Of the 607 questionnaires sent by first class mail, 114 responses were received, with another 17 questionnaires coming back as return to sender. Of the 35 questionnaires sent by email, 19 responses were received, with 4 of those being removed for failing to provide information required for data analysis and being incomplete to the point that the research team questioned the integrity of the entire survey response. In total, 129 completed questionnaires were received from 98 conventional, 26 organic, and 5 unspecified dairy farms, from a sample population of 590 potential participants ( $22 \%$ response rate). The total population response rate for all active dairy farms in New England was $10 \%$ for organic farms, $4 \%$ for conventional farms and $5 \%$ when combining both (Table 1).

The distribution of dairy farm responses by state between the sample and target population were similar, with 5 of the 6 sampled states having a distribution within $3 \%$ of each other (Table 1). Only Maine dairy farmers were slightly underrepresented when comparing the distributions on a regional level. However, response rate in relation to herd size (lactating cows) was slightly skewed between sample and target populations (Table 2). Whereas the distribution of farms between the sample and target population was similar for the 2 larger classes, smaller dairies $(\leq 49$ cows) were slightly underrepresented in the study.

\section{Bedding Usage and Quantity}

The primary bedding materials used by conventional dairy farmers were sawdust, sand, and wood shavings, with 52,24 , and $14 \%$ of dairy farms using those bedding 
Table 1. Response rate distribution by state in relation to New England dairy farm population

\begin{tabular}{|c|c|c|c|c|c|}
\hline \multirow[b]{2}{*}{ State } & \multicolumn{2}{|c|}{ Dairy farms in New England ${ }^{1}$} & \multicolumn{2}{|c|}{ Completed questionnaires } & \multirow[b]{2}{*}{ Total population response rate (\%) } \\
\hline & $\mathbf{N}$ & Distribution (\%) & $\mathbf{N}$ & Distribution (\%) & \\
\hline Maine & 581 & 24 & 18 & 14 & 3.1 \\
\hline Vermont & 1,075 & 44 & 58 & 45 & 5.4 \\
\hline New Hampshire & 251 & 10 & 17 & 13 & 6.8 \\
\hline Massachusetts & 278 & 11 & 14 & 11 & 5.0 \\
\hline Connecticut & 242 & 10 & 9 & 7 & 3.7 \\
\hline Rhode Island & 30 & 1 & 2 & 1 & 6.7 \\
\hline Unspecified & 0 & 0 & 11 & 9 & 0 \\
\hline Total & 2,457 & 100 & 129 & 100 & 5.3 \\
\hline
\end{tabular}

${ }^{1}$ USDA (2012).

materials as their primary selection, respectively. A few conventional dairy farmers also used manure solids (MNS; composed or digested) and hay, with those bedding materials representing 3 and $4 \%$, respectively (Table 3 ). When analyzing just woody bedding (sawdust and wood shavings), respondents from conventional dairies reported using $11 \mathrm{~m}^{3} /$ cow per year.

The primary bedding materials used by organic dairy farmers were sawdust, sand, and hay, with 65,12 , and $12 \%$ of dairy farmers using those bedding materials as their main selection, respectively (Table 3 ). Straw, wood shavings, and wood chips were also used, but only represented $4 \%$ each. With regard to woody bedding, respondents from organic dairy farms used the same quantity as conventional dairy farmers $\left(11 \mathrm{~m}^{3} /\right.$ cow per year $)$.

When examining bedding material selections further for both conventional and organic dairy farmers, only $5(3 \%)$ did not use any woody bedding in their mix. Of those respondents, 4 used hay exclusively and the other used a combination of sand and straw. Given that the region is $78 \%$ forested (Foster et al., 1998), the popularity of woody bedding was not surprising. Geography is also the likely reason for the lack of straw bedding used by respondents; the New England region produces minimal quantities of cereal crops for straw by-product (USDA, 2015). Of the 20 dairy farmers in the sample population using some straw, $90 \%$ reported straw as $<10 \%$ of total bedding usage.

\section{Bedding Preference}

Conventional and organic dairy farmer responses for why they preferred their primary bedding material varied by bedding type (Table 4). Dairy farmers using sand cited low bacteria as a top reason, which is a characteristic well supported in the literature (Hogan et al., 1989; Godden et al., 2008). Farmers using sawdust cited the ease of material handling and absorbency as primary benefits. Zehner et al. (1986) also reported the high absorbency of sawdust. Farmers using wood shavings reported dryness and ease of handling as primary benefits, and those using hay found the ability to grow it on site to be a top preference. Dyck et al. (2009) also reported the advantage of growing hay on site as a bedding source, especially for organic dairy farmers, who are required to use more expensive organiccertified bedding. Dairy farmers using MNS reported high absorbency as their top preference, which is a characteristic reported by Zehner et al. (1986) in a study of 5 different bedding materials.

\section{Bedding Avoidance}

Of the 71 conventional and organic dairy farmers (55\%) reporting a particular bedding avoidance, $59 \%$ avoided sand, with incompatibility with the manure system and wear on equipment being the top reasons for not using the material (Table 5). Dyck et al. (2009) also reported the

Table 2. New England lactating herd size distribution between sample and target populations

\begin{tabular}{lcc} 
Dairy farm size class & $\begin{array}{c}\text { Target population size class distribution }{ }^{1} \\
(\%)\end{array}$ & $\begin{array}{c}\text { Survey sample population size class distribution } \\
\text { (\%) }\end{array}$ \\
\hline$\leq 49$ Cows & 57 & 37 \\
$50-99$ Cows & 20 & 38 \\
$100-199$ Cows & 11 & 14 \\
$\geq 200$ Cows & 11 & 12 \\
\hline
\end{tabular}

${ }^{1}$ USDA (2012). 
Table 3. Primary bedding materials used at conventional and organic dairy farms across New England

\begin{tabular}{lrcccccc} 
& \multicolumn{6}{c}{ Number of farms using specified bedding material } \\
\cline { 2 - 7 } Management system & Sand & Sawdust & Shavings & Hay & MNS & Straw & Other \\
\hline Conventional (98) & 23 & 51 & 14 & 4 & 3 & 0 & 3 \\
Organic (26) & 3 & 17 & 1 & 3 & 0 & 1 & 1 \\
\hline
\end{tabular}

${ }^{1} \mathrm{MNS}=$ manure solids; Other = wood chips, leaves, horse litter, ground cornhusks, and Clean Cow Bedding from Casella Organics (Saco, ME).

incompatibility of sand with manure systems. The next most avoided bedding material was straw, which was cited as being too costly, difficult to handle, and not compatible with liquid manure systems. A study of Vermont bedded pack dairy facilities also found that straw was regionally expensive (Gilker, 2012). Hay was the third most avoided material, with respondents reporting similar issues to straw, only without the high cost. Sawdust was the fourth most avoided bedding material, with bacteria concerns being the main reason for avoidance. Hogan et al. (1989) and Zdanowicz et al. (2004) both described the ability of sawdust to support mastitis-causing bacteria, especially Klebsiella spp. High bacteria counts were also the primary reason respondents avoided MNS, which is a characteristic supported in the literature (Zehner et al., 1986; Godden et al., 2008; Harrison et al., 2008). Interestingly, none of the surveyed organic farmers used any quantity of MNS.

\section{Bedding Cost and Material Conversion over the Past Decade}

From 2003 to 2013 average regional bedding material costs, with inflation accounted for, increased by $70 \%$ for conventional dairy farm respondents. Conventional dairy farmers paid an average of $\$ 184 /$ cow per year for bedding material in 2013, compared with $\$ 85 /$ cow per year in 2003 (Table 6). During this same period, the cost of bedding material for organic dairy farmers increased from $\$ 67 /$ cow per year in 2003 to $\$ 145 /$ cow per year in 2013 (Table 6). After accounting for inflation, this translates to a $71 \%$ increase in bedding material costs.

When analyzing bedding material cost, only $5 \%$ of respondents ( 6 conventional and 1 organic dairy farmer) did not have increased costs over the 10-yr period (2003 to 2013). This finding was consistent with that of Laughton et al. (2014), who also reported the increasing cost of dairy supplies throughout New England, which included bedding. Of the dairy farmers not reporting increased cost, 2 were using sand, 1 was using sawdust, 1 switched to using MNS, 1 purchased a wood shaving machine, and 1 was growing hay onsite. Of the farmers using woody bedding, 98\% experienced increased costs from 2003 to 2013.

When respondents were asked whether they switched bedding materials from 2003 to 2013, 34 farmers $(26 \%)$ reported switching primary bedding materials, with $82 \%$

Table 4. Reason for preferring a bedding material and number of dairy farmers supporting that reason

\begin{tabular}{lcccccc} 
& \multicolumn{6}{c}{ Number of responses by bedding material type } \\
\cline { 2 - 6 } Preference characteristic & Sand & Sawdust & Shavings & Hay & Straw & MNS $^{1}$ \\
\hline Dry & 1 & - & 9 & - & - & - \\
Clean & 3 & - & 3 & - & 1 & 1 \\
Comfortable & 2 & 2 & 1 & - & - & 1 \\
Absorbent & - & 6 & 2 & - & - & 3 \\
Low bacteria & 10 & 3 & 3 & - & - & 1 \\
Can be purchased locally & 3 & - & 4 & 1 & - & - \\
Can be grown on site & - & - & - & 4 & 1 & - \\
Can be produced on site & 4 & - & - & - & - & 2 \\
Easy handling & - & 13 & 4 & 1 & - & - \\
Low cost & 4 & 4 & 1 & 1 & - & 2 \\
Visually appealing & - & 1 & - & - & - & - \\
Manure system compatibility & - & 1 & 2 & 1 & - & 1 \\
\hline
\end{tabular}

${ }^{1} \mathrm{MNS}=$ manure solids. 
Table 5. Reason for avoiding a bedding material and number of dairy farmers supporting that reason

Number of responses by bedding material type

\begin{tabular}{lcccccc} 
Avoidance characteristic & Sand & Sawdust & Shavings & Hay & Straw & MNS $^{1}$ \\
\hline Not absorbent & - & - & 2 & 1 & - & - \\
Dirty & - & - & - & 1 & 1 & 1 \\
High bacteria & - & 7 & 2 & 1 & - & 3 \\
Hard on equipment & 12 & - & - & - & - & - \\
Unsuited with housing system & 6 & - & - & - & - & 1 \\
Expensive & 1 & 1 & 2 & 3 & 10 & - \\
Not readily available & 1 & 2 & 1 & - & 1 & 1 \\
Difficulty with handling & 4 & - & - & 5 & 6 & - \\
Smells bad when wet & - & - & - & 1 & - & - \\
Avoid for no particular reason & - & 2 & - & - & - & - \\
Incompatible with manure system & 18 & - & - & 11 & 10 & - \\
\hline
\end{tabular}

${ }^{1} \mathrm{MNS}=$ manure solids .

of respondents converting from sawdust or shavings to a nonwoody bedding type. The primary reasons cited for switching from woody bedding were mill closings (12 farmers), switched to sand ( 7 farmers), and increased cost (6 farmers).

\section{Bedding Rank Compared with Other Farming Expenses}

In comparing bedding cost in relation to other farming expenses, conventional dairy farmers ranked bedding fourth most expensive, whereas organic dairy farmers ranked bedding fifth. Cost of imported feed and labor were ranked first and second for both conventional and organic dairy farmers (Table 7). A study of 142 dairy farms in New England by Laughton et al. (2014) reported a similar ranking of costs for conventional dairy farmers, with the following costs per cow per year: feed $(\$ 1,948)$; labor (\$802); repairs (\$343); supplies $(\$ 255)$; and gasoline, fuel, and oil (\$254). However, bedding cost was not a specific line item in their economic analysis but was contained within the supplies category and was often the highest cost within that category (C. Laughton, 2016, Farm Cred- it East, 174 South Road, Enfield, CT, personal communication).

\section{Relationship Between Bedding Material with Cost and Producer-Reported SCC}

On conventional dairy farms, respondents using wood shavings reported the highest bedding material costs (\$286/cow per year), whereas those using MNS reported the lowest costs $(\$ 34 /$ cow per year) (Table 8$)$. For organic dairies, the cost of wood shavings was also the most expensive material ( $\$ 195 /$ cow per year $)$, with sand being the least expensive ( $\$ 76 /$ cow per year). For both management systems, large variability existed between and within bedding materials, as shown by the high SD in Table 8. However, for both management systems, woody bedding tended to be more expensive than other bedding materials.

Few studies have specifically focused on the cost comparison between various bedding materials to serve as a comparison to this study. However, Harrison et al. (2008) reported similar findings regarding the low cost associated with MNS. In their study, dairy farmers switching to MNS

Table 6. Bedding cost comparison between 2003 and 2013 for organic and conventional dairy farms

\begin{tabular}{|c|c|c|c|c|c|c|c|c|c|c|c|c|}
\hline \multirow{3}{*}{$\begin{array}{l}\text { Management } \\
\text { system }\end{array}$} & \multicolumn{6}{|c|}{ Bedding cost per cow $(\$)$} & \multicolumn{6}{|c|}{ Bedding cost per head (\$) } \\
\hline & \multicolumn{3}{|c|}{2013} & \multicolumn{3}{|c|}{2003} & \multicolumn{3}{|c|}{2013} & \multicolumn{3}{|c|}{2003} \\
\hline & Mean & SD & Median & Mean & SD & Median & Mean & SD & Median & Mean & SD & Median \\
\hline Conventional (60) & 184 & 173 & 125 & 85 & 74 & 68 & 87 & 74 & 65 & 41 & 40 & 32 \\
\hline Organic (16) & 145 & 69 & 150 & 67 & 49 & 53 & 70 & 36 & 73 & 34 & 24 & 26 \\
\hline
\end{tabular}


Table 7. Rank of bedding cost in relation to other farming expenses

\begin{tabular}{|c|c|c|c|c|c|c|}
\hline \multirow[b]{2}{*}{ Rank of costs } & \multicolumn{3}{|c|}{ Conventional dairies $(n=102)$} & \multicolumn{3}{|c|}{ Organic dairies $(n=23)$} \\
\hline & Cost & Score $^{1}$ & No. & Cost & Score $^{1}$ & No. \\
\hline 1 & Feed & 970 & 100 & Feed & 220 & 23 \\
\hline 2 & Labor & 364 & 50 & Labor & 70 & 9 \\
\hline 3 & Repairs & 226 & 47 & Fuel & 62 & 12 \\
\hline 4 & Bedding & 224 & 46 & Repairs & 58 & 12 \\
\hline 5 & Fuel & 194 & 41 & Bedding & 54 & 15 \\
\hline
\end{tabular}

${ }^{1}$ Score based on number of responses (no.) and the associated rank (rank $1=10$, rank $2=8$, rank $3=6$, rank $4=4$, and rank $5=2$ ).

reported a savings of $\$ 0.01$ to $\$ 0.26$ per $45.36 \mathrm{~kg}$ (hundredweight) when considering bedding purchases and manure handling. A second study by Panivivat et al. (2004) also mentioned bedding costs briefly for dairy calves in Arkansas. In their study, long wheat straw and sand were the most expensive bedding materials, followed by granite fines, wood shavings, and rice hulls.

When examining average producer-reported SCC, sawdust was slightly elevated on conventional dairy farms (168,696 cells/mL), whereas wood shavings were highest for those using organic management $(160,000$ cells $/ \mathrm{mL})$ (Table 8). The bedding material with the lowest average SCC on conventional dairies was wood shavings (134,077 cells $/ \mathrm{mL}$ ), and sand was the lowest for organic dairies $(119,667$ cells $/ \mathrm{mL})$. For both management systems, large variability existed in the producer-reported SCC between and within bedding materials (Table 8).

In comparing producer-reported SCC values from respondents in this study to that of other studies, some trends are apparent. In the present study, sawdust exhibited elevated SCC for both management systems. Numerous studies have reported that sawdust harbors more mastitis-causing bacteria, especially Klebsiella spp., when compared with other bedding types (Hogan et al., 1989; Zdanowicz et al., 2004; Dyck et al., 2009). With bacterial counts in bedding corresponding to rates of clinical mastitis (Hogan et al., 1989), it is likely that the elevated SCC reported on farms using sawdust bedding was due to the bedding material itself and not some form of management. This is especially true because dairy farmers reported using sawdust across all housing types, farm scale, and in both management systems.

A second trend, although not as strong due to small sample size, was the lower average SCC values reported by respondents using sand. A review by Dufour et al. (2011) reported that sand bedding was associated with lower SCC. Wenz et al. (2007) also found that mattresses, sand, and newspaper were all associated with lower SCC, when

Table 8. Cost and SCC for various bedding materials for conventional and organic dairy herds across New England

\begin{tabular}{|c|c|c|c|c|c|c|c|c|c|}
\hline \multirow[b]{3}{*}{ Primary material } & \multicolumn{6}{|c|}{ Per cow } & \multirow{2}{*}{\multicolumn{3}{|c|}{$\frac{\text { Per head }}{\text { Bedding cost }(\$)}$}} \\
\hline & \multicolumn{3}{|c|}{ Bedding cost (\$) } & \multicolumn{3}{|c|}{ SCC (cells/mL) } & & & \\
\hline & Mean & SD & Median & Mean & SD & Median & Mean & SD & Median \\
\hline \multicolumn{10}{|l|}{ Conventional } \\
\hline Sawdust (47) & 213 & 187 & 144 & 168,696 & 111,336 & 150,000 & 102 & 80 & 76 \\
\hline Sand (19) & 132 & 94 & 106 & 135,000 & 40,997 & 130,000 & 63 & 48 & 49 \\
\hline Shavings (11) & 286 & 139 & 311 & 134,077 & 63,043 & 110,000 & 126 & 62 & 130 \\
\hline Other (5) & 112 & 61 & 144 & 164,333 & 61,776 & 200,000 & 42 & 35 & 50 \\
\hline $\mathrm{MNS}^{1}(3)$ & 34 & 10 & 28 & 134,333 & 46,004 & 135,000 & 16 & 2 & 15 \\
\hline \multicolumn{10}{|l|}{ Organic } \\
\hline Sawdust (17) & 134 & 71 & 132 & 142,750 & 34,492 & 140,000 & 66 & 35 & 64 \\
\hline Sand (2) & 76 & 40 & 76 & 119,667 & 53,295 & 100,000 & 55 & 38 & 49 \\
\hline Shavings (2) & 195 & 64 & 195 & 160,000 & 0 & 160,000 & 120 & 0 & 120 \\
\hline Hay (2) & 169 & 27 & 169 & 133,333 & 56,862 & 150,000 & 109 & 0 & 109 \\
\hline Other (1) & 133 & 0 & 133 & 132,500 & 45,962 & 132,500 & 82 & 2 & 82 \\
\hline
\end{tabular}

${ }^{1} \mathrm{MNS}=$ manure solids. 
Table 9. Cost and SCC in relation to housing type

\begin{tabular}{|c|c|c|c|c|c|c|c|c|c|}
\hline \multirow[b]{3}{*}{ Housing type ${ }^{1}$} & \multicolumn{6}{|c|}{ Per cow } & \multirow{2}{*}{\multicolumn{3}{|c|}{$\begin{array}{c}\text { Per head } \\
\text { Bedding cost }(\$)\end{array}$}} \\
\hline & \multicolumn{3}{|c|}{ Bedding cost (\$) } & \multicolumn{3}{|c|}{ SCC (cells/mL) } & & & \\
\hline & Mean & SD & Median & Mean & SD & Median & Mean & SD & Median \\
\hline \multicolumn{10}{|l|}{ Conventional } \\
\hline TS (27) & 236 & 223 & 136 & 182,125 & 143,183 & 150,000 & 114 & 95 & 65 \\
\hline FS (19) & 108 & 90 & 92 & 134,167 & 39,453 & 132,500 & 54 & 45 & 46 \\
\hline $\mathrm{BP}(2)$ & 425 & 26 & 425 & 110,000 & 14,142 & 110,000 & 186 & 1 & 186 \\
\hline $\mathrm{FS}+\mathrm{BP}(14)$ & 131 & 122 & 101 & 141,286 & 62,610 & 117,500 & 65 & 58 & 47 \\
\hline $\mathrm{TS}+\mathrm{BP}(11)$ & 253 & 111 & 268 & 145,000 & 62,530 & 125,000 & 128 & 57 & 128 \\
\hline $\mathrm{TS}+\mathrm{FS}(7)$ & 144 & 61 & 151 & 133,000 & 41,833 & 134,000 & 68 & 27 & 64 \\
\hline $\mathrm{TS}+\mathrm{FS}+\mathrm{BP}(6)$ & 270 & 104 & 304 & 151,500 & 69,529 & 180,500 & 104 & 38 & 112 \\
\hline \multicolumn{10}{|l|}{ Organic } \\
\hline TS (7) & 179 & 59 & 77 & 147,143 & 10,746 & 150,000 & 86 & 28 & 77 \\
\hline FS (6) & 64 & 34 & 26 & 123,333 & 32,042 & 110,000 & 37 & 31 & 26 \\
\hline $\mathrm{BP}(4)$ & 177 & 47 & 96 & 151,250 & 35,208 & 162,500 & 98 & 20 & 96 \\
\hline $\mathrm{FS}+\mathrm{BP}(1)$ & 105 & 0 & 56 & 120,000 & 0 & 120,000 & 56 & 0 & 56 \\
\hline $\mathrm{TS}+\mathrm{BP}(2)$ & 107 & 66 & 46 & 197,000 & 74,953 & 197,000 & 46 & 32 & 46 \\
\hline $\mathrm{TS}+\mathrm{FS}(2)$ & 147 & 107 & 71 & 140,000 & 28,284 & 140,000 & 71 & 45 & 71 \\
\hline $\mathrm{TS}+\mathrm{FS}+\mathrm{BP}(2)$ & 163 & 18 & 88 & 150,000 & 0 & 150,000 & 88 & 11 & 88 \\
\hline
\end{tabular}

${ }^{1} \mathrm{TS}=$ tie-stall, $\mathrm{FS}=$ freestall, $\mathrm{BP}=$ bedded pack.

compared with composted manure, which was 2.9 times more likely to have elevated SCC.

\section{Relationship Between Housing Type with Bedding Cost and SCC}

For conventional dairy farmers, the average cost of bedding material for those using bedded packs was the highest ( $\$ 425 /$ cow per year), whereas the cost of bedding material for those using freestalls was the lowest $(\$ 108 /$ cow per year). The same trend was also found for dairy farmers using organic management, with bedding material for those using bedded packs costing $\$ 177 /$ cow per year versus $\$ 64$ / cow per year for those using freestalls (Table 9 ).

Few studies have explored the relationship between housing type and bedding cost to serve as a comparison to this study. However, a study by Endres (2012) reported similar results, with the cost of bedding being highest for dairy farmers using bedded packs ( $\$ 146$ to $\$ 347 /$ cow per year) compared with farmers using freestalls ( $\$ 33$ to $\$ 55 /$ cow per year). The higher cost of bedded packs was also reported by Gilker (2012), who found that bedded packs use 4 times as much bedding material as freestall barns. Barberg et al. (2007) also reported that the cost of bedding for packs ( $\$ 128$ to $\$ 310 /$ cow per year) was the greatest concern for those using that housing type. However, Barberg et al. (2007) also reported a reduced occurrence of lameness and increased cow comfort on bedded packs, which may offset the extra cost of more bedding material.

When analyzing average producer-reported SCC in relation to housing type, few trends are apparent, due to the large variability between and within housing types, and the small sample size for some factors. However, in general, average SCC tended to be less on farms with freestall housing (Table 9). These findings were in agreement with Rodrigues et al. (2005) and Dufour et al. (2011), who reported that freestall systems are associated with lower SCC, when compared with other housing types.

\section{Relationship Between Dairy Cow Herd Size with Bedding Cost and SCC}

Economies of scale were found for bedding cost as herd size increased on conventional farms. The average cost of bedding material went from $\$ 258 /$ cow per year for the smallest size class ( $\leq 49$ cows) down to $\$ 111 /$ cow per year for the largest size class ( $\geq 200$ cows) (Table 10). Economies of scale were also present on organic dairy farms, with average bedding cost decreasing as herd size increased. Dairy farms in the smallest size class $(\leq 49$ cows $)$ paid an average of $\$ 160 /$ cow per year compared with the largest size class (100-199 cows), which had bedding material costs of $\$ 104 /$ cow per year (Table 10).

The relationship between increasing bedding cost and decreasing herd size is a consistent trend in the literature. In a study of Northeast dairy farms, Laughton et al. (2014) reported that larger farms had lower production costs (including bedding) from economies of scale. MacDonald et al. (2007) also reported reduced costs associated with economies of scale for conventional dairies, and McBride and Greene (2009) reported the same trend for organic dairies. A review of the literature by Tauer 
and Mishra (2006) also concluded that the higher cost of production on smaller dairies in the United States was associated with inefficiency rather than varying technology.

In comparing farm scale to self-reported SCC, no predictable trend was observed. Conventional dairy farmers reported averages of 129,417 cells/mL for the smallest size class to 145,929 cells $/ \mathrm{mL}$ for the largest size class $(\geq 200$ cows; Table 10). Organic dairy farms reported similar findings, with regional averages of 132,833 cells/mL in the smallest size class to 136,667 cells $/ \mathrm{mL}$ in the largest size class (100-199 cows) (Table 10). These results are inconsistent with the findings reported in the literature. A study of Wisconsin dairy farms by Ingham et al. (2011) found that small farms ( $\leq 118$ cows) had significantly higher SCC (369,000 cells/mL) when compared with the large farms (119 to 713 cattle) or confined animal feeding operations ( $\geq 714$ cattle), which had SCC of 273,000 and 240,000 cells/mL, respectively. Similarly, Allore et al. (1997), Oleggini et al. (2001), and Archer et al. (2013) all reported decreasing SCC with increasing herd size.

\section{Relationship Between Management System with Bedding Cost and SCC}

The average cost of bedding material for conventional dairy farmers was $\$ 184 /$ cow per year, compared with organic dairy farmers, who spent an average of $\$ 145 /$ cow per year (Table 6). However, median values differed, with organic dairy farmers paying more $(\$ 150 /$ cow per year) versus conventional farmers ( $\$ 125 /$ cow per year), illustrating the variability of bedding costs within each management system. In comparison with other studies, McBride and Greene (2009) found that organic dairies tended to have higher operating costs than conventional farms. However, they also reported that organic dairies tended to be smaller than conventional dairies, with economies of scale resulting in reduced cost for both management systems. With the strongest trend between bedding costs being farm size in the present study, it is likely that the higher material costs reported in McBride and Greene (2009) were a result of farm size and not specifically the management system.

When examining self-reported SCC, there was no obvious trend between management systems. Conventional dairy farm respondents reported an average of 152,318 cells/mL, compared with organic dairy farmers, who reported an average of 138,720 cells/mL. The similarity between conventional and organic dairy farms with SCC is consistent in the literature. Stiglbauer et al. (2013) reported similar results between conventional (213,000 cells/mL) and organic $(221,000$ cells/mL) dairy farms in New York, Wisconsin, and Oregon. Similarly, Sato et al. (2005), Pol and Ruegg (2007), and Haskell et al. (2009) all reported no difference in SCC between organic and conventional dairy farms.

\section{Interest in Producing Bedding with a Wood Shaving Machine}

Of the dairy farmers surveyed, $99(77 \%)$ reported owning a woodlot, with an average ownership of 64 ha. The primary uses for these woodlots were firewood and timber production. When asked whether they would be interested in participating in local farmer cooperatives to produce their own wood shavings, $13 \%$ of respondents said yes, $42 \%$ said maybe, and $45 \%$ said no. Of the respondents saying yes, $82 \%$ were owners of farms with $\leq 99$ cows, $18 \%$ owned 100 to 199 cows, and $0 \%$ said yes for the largest size class $(\geq 200$ cows). When asked whether they would purchase wood shavings from local cooperatives, $20 \%$ of the sampled farmers said yes, $17 \%$ said no, and $63 \%$ said maybe. Of those saying yes, $79 \%$ were owners of farms with $\leq 99$ cows. When asked whether the wood shavings would have to be kiln dried, $63 \%$ said yes, $19 \%$ said no, and $18 \%$ were unsure.

The greater interest in producing bedding with a wood shaving machine from dairy farm owners with smaller herds was not surprising. The cost of bedding per cow for survey respondents in the smaller size classes was al-

Table 10. Cost and SCC in relation to farm size

\begin{tabular}{|c|c|c|c|c|c|c|c|c|c|}
\hline \multirow[b]{3}{*}{ Size class } & \multicolumn{6}{|c|}{ Per cow } & \multirow{2}{*}{\multicolumn{3}{|c|}{$\begin{array}{c}\text { Per head } \\
\text { Bedding cost }(\$)\end{array}$}} \\
\hline & \multicolumn{3}{|c|}{ Bedding cost (\$) } & \multicolumn{3}{|c|}{ SCC (cells/mL) } & & & \\
\hline & Mean & SD & Median & Mean & SD & Median & Mean & SD & Median \\
\hline \multicolumn{10}{|l|}{ Conventional } \\
\hline$\leq 49$ Cows $(22)$ & 258 & 211 & 147 & 129,417 & 50,540 & 117,500 & 109 & 82 & 72 \\
\hline 50-99 Cows (34) & 191 & 125 & 151 & 160,829 & 123,345 & 140,000 & 94 & 60 & 83 \\
\hline 100-199 Cows (15) & 129 & 79 & 111 & 169,714 & 57,046 & 177,500 & 64 & 40 & 49 \\
\hline$\geq 200$ Cows $(12)$ & 111 & 97 & 75 & 145,929 & 39,191 & 132,500 & 57 & 51 & 36 \\
\hline \multicolumn{10}{|l|}{ Organic } \\
\hline$\leq 49$ Cows $(12)$ & 160 & 69 & 154 & 132,833 & 37,634 & 137,500 & 80 & 36 & 82 \\
\hline 50-99 Cows (10) & 125 & 72 & 132 & 146,400 & 43,470 & 147,000 & 61 & 36 & 63 \\
\hline 100-199 Cows (3) & 104 & 7 & 105 & 136,667 & 15,275 & 140,000 & 68 & 22 & 56 \\
\hline
\end{tabular}


most twice the cost of those in the largest size class $(\geq 200$ cows). A primary reason for this is due to economies of scale, where owners of small dairy farms are less likely to order bulk purchases of bedding. This is especially true for the most common bedding sources in New England-sawdust and shavings. Many of the mills in the region that supply this bedding source will blow the sawdust or mill shavings into a tractor trailer, delivering over $75 \mathrm{~m}^{3}$ at a time. For many smaller dairy farms in the region, this type of purchase would result in storing large quantities of bedding for an extended length of time, increasing the risk of contamination.

\section{IMPLICATIONS}

This case study of 98 conventional and 26 organic dairy farmers from across the New England region is the first to take such a comprehensive financial view of animal bedding cost and SCC in relation to bedding material type, housing system, herd size, and management system. For the surveyed conventional and organic dairy farmers, bedding cost ranked fourth and fifth most costly in relation to other farm expenses. Economies of scale were found with bedding material purchases, with cost decreasing as herd size increased. This has important management implications beyond the New England region; smaller dairies could reduce their bedding costs substantially by purchasing material in bulk like larger operations. Alternatively, a collection of locally clustered dairies may benefit by purchasing bulk orders together and dividing material afterward. Finally, the authors hope this study starts a conversation among practitioners and researchers about animal bedding costs in their region, hopefully leading to cost-saving solutions for those in the industry.

\section{ACKNOWLEDGMENTS}

The authors of this survey study thank the 129 New England dairy farmers who completed the questionnaire that made this study possible. We also thank Juan Alvez and Jennifer Colby from the University of Vermont for their assistance with the development of the questionnaire. We also thank Ted Howard from the University of New Hampshire for financial assistance with the survey mailings. Funding was provided by the New Hampshire Agricultural Experiment Station. This is Scientific Contribution Number 2697. This work was supported by the USDA National Institute of Food and Agriculture McIntire-Stennis NH00073-M Project (0231860). Sponsors of financial support were independent of data collection, analysis, and publication of this article.

\section{LITERATURE CITED}

Allore, H. G., P. A. Oltenacu, and H. N. Erb. 1997. Effects of season, herd size, and geographic region on the composition and quality of milk in the northeast. J. Dairy Sci. 80:3040-3049. https://doi.org/10 .3168/jds.S0022-0302(97)76271-4.
Archer, S. C., F. M. Coy, W. Wapenaar, and M. J. Green. 2013. Association of season and herd size with somatic cell count for cows in Irish, English, and Welsh dairy herds. Vet. J. 196:515-521. https://doi .org/10.1016/j.tvjl.2012.12.004.

Barberg, A. E., M. I. Endres, J. A. Salfer, and J. K. Reneau. 2007. Performance and welfare of dairy cows in an alternative housing system in Minnesota. J. Dairy Sci. 90:1575-1583. https://doi.org/10 .3168/jds.S0022-0302(07)71643-0.

Dillman, D. A. 2000. Internet and Mail Surveys: The Tailored Design Method. John Wiley, New York, NY.

Dufour, S., A. Frechette, H. W. Barkema, A. Mussell, and D. T. Scholl. 2011. Invited review: Effect of udder health management practices on herd somatic cell count. J. Dairy Sci. 94:563-579. https://doi .org/10.3168/jds.2010-3715.

Dyck, E., S. Flack, K. Hoffman, E. Maltby, K. Mendenhall, R. Perry, S. Richards, L. Tikofsky, and B. Wallis. 2009. The Organic Dairy Handbook: A Comprehensive Guide for the Transition and Beyond. K. Mendenhall, ed. Northeast Organ. Farm. Assoc. New York Inc., New York, NY.

Endres, M. I. 2012. Bedding options for dairy cows. Western Canadian Dairy Seminar (WCDS): Adv. Dairy Tech. 24:361-369.

Foster, D. R., G. Motzkin, and B. Slater. 1998. Land-use history as long-term broad-scale disturbance: Regional forest dynamics in central New England. Ecosystems (N. Y.) 1:96-119. https://doi.org/10 $.1007 / \mathrm{s} 100219900008$.

Gilker, R. E. 2012. Bedded Pack in Vermont: Five Stories. Univ. Vermont-Ext., Burlington.

Godden, S., R. Bey, K. Lorch, R. Farnsworth, and P. Rapnicki. 2008. Ability of organic and inorganic bedding materials to promote growth of environmental bacteria. J. Dairy Sci. 91:151-159. https://doi.org/ 10.3168/jds.2007-0415.

Harrison, E., J. Bonhotal, and M. Schwarz. 2008. Using Manure Solids as Bedding. Cornell Waste Manage. Inst., Ithaca, NY.

Haskell, M. J., F. M. Langford, M. C. Jack, L. Sherwood, A. B. Lawrence, and K. M. D. Rutherford. 2009. The effect of organic status and management practices on somatic cell counts on UK dairy farms. J. Dairy Sci. 92:3775-3780. https://doi.org/10.3168/jds.2009-2105.

Hogan, J. S., K. L. Smith, K. H. Hoblet, D. A. Todhunter, P. S. Schoenberger, W. D. Hueston, D. E. Pritchard, G. L. Bowman, L. E. Heider, B. L. Brockett, and H. R. Conrad. 1989. Bacterial counts in bedding materials used on nine commercial dairies. J. Dairy Sci. 72:250-258. https://doi.org/10.3168/jds.S0022-0302(89)79103-7.

Ingham, S. C., Y. Hu, and C. Ane. 2011. Comparison of bulk-tank standard plate count and somatic cell count for Wisconsin dairy farms in three size categories. J. Dairy Sci. 94:4237-4241. https://doi.org/ 10.3168/jds.2011-4310.

Laughton, C., N. Flint, and S. Petig. 2014. 2013 Northeast Dairy Farm Summary. Farm Credit East, Agric. Credit Assoc. Yankee Farm Credit, ACA, Washington, DC.

MacDonald, J. M., E. J. O'Donoghue, W. D. McBride, R. F. Nehring, C. L. Sandretto, and R. Mosheim. 2007. Profits, Costs, and the Changing Structure of Dairy Farming. Economic Res. Rep. No. 47. ARS-USDA, Washington, DC.

McBride, W. D., and C. Greene. 2009. Characteristics, Costs, and Issues for Organic Dairy Farming. Economic Res. Rep. No. 82. ARSUSDA, Washington, DC.

Oleggini, G. H., L. O. Ely, and J. W. Smith. 2001. Effect of region and herd size on dairy herd performance parameters. J. Dairy Sci. 84:1044-1050. https://doi.org/10.3168/jds.S0022-0302(01)74564-X.

Panivivat, R., E. B. Kegley, J. A. Pennington, D. W. Kellogg, and S. L. Krumpelman. 2004. Growth performance and health of dairy calves 
bedded with different types of materials. J. Dairy Sci. 87:3736-3745. https://doi.org/10.3168/jds.S0022-0302(04)73512-2.

Pol, M., and P. L. Ruegg. 2007. Treatment practices and quantification of antimicrobial drug usage in conventional and organic dairy farms in Wisconsin. J. Dairy Sci. 90:249-261. https://doi.org/10 .3168/jds.S0022-0302(07)72626-7.

Rodrigues, A. C. O., D. Z. Caraviello, and P. L. Ruegg. 2005. Management of Wisconsin dairy herds enrolled in milk quality teams. J. Dairy Sci. 88:2660-2671. https://doi.org/10.3168/jds.S0022-0302(05)72943 $-\mathrm{X}$.

Ruegg, P. L. 2006. The role of hygiene in efficient milking. Western Canadian Dairy Seminar (WCDS): Adv. Dairy Tech. 18:285-293.

Sato, K., P. C. Bartlett, R. J. Erskine, and J. B. Kaneene. 2005. A comparison of production and management between Wisconsin organic and conventional dairy herds. Livest. Prod. Sci. 93:105-115. https://doi.org/10.1016/j.livprodsci.2004.09.007.

Sivo, S. A., C. Saunders, Q. Chang, and J. J. Jiang. 2006. How low should you go? Low response rates and the validity of inference in IS questionnaire research. J. Assoc. Inf. Syst. 7:351-414.

Stiglbauer, K. E., K. M. Cicconi-Hogan, R. Richert, Y. H. Schukken, P. L. Ruegg, and M. Gamroth. 2013. Assessment of herd management on organic and conventional dairy farms in the United States. J. Dairy Sci. 96:1290-1300. https://doi.org/10.3168/jds.2012-5845.

Tauer, L. W., and A. K. Mishra. 2006. Can the small dairy farm remain competitive in U.S. agriculture? Food Policy 31:458-468. https://doi.org/10.1016/j.foodpol.2005.12.005.
Tucker, C. B., D. M. Weary, M. A. G. von Keyserlingk, and K. A. Beauchemin. 2009. Cow comfort in tie-stalls: Increased depth of shavings or straw bedding increases lying time. J. Dairy Sci. 92:2684-2690. https://doi.org/10.3168/jds.2008-1926.

USDA. 2012. Census of Agriculture. USDA, Washington, DC.

USDA. 2014. Organic Survey. AC-12-SS-4. USDA, Washington, DC.

USDA. 2015. Crop Production 2014 Summary. Natl. Agric. Stat. Serv., Washington, DC.

Wenz, J. R., S. M. Jensen, J. E. Lombard, B. A. Wagner, and R. P. Dinsmore. 2007. Herd management practices and their association with bulk tank somatic cell count on United States dairy operations. J. Dairy Sci. 90:3652-3659. https://doi.org/10.3168/jds.2006-592.

Woodall, C. W., W. G. Luppold, P. J. Ince, R. J. Piva, and K. E. Skog. 2012. An assessment of the downturn in the forest products sector in the northern region of the United States. For. Prod. J. 61:604-613.

Zdanowicz, M., J. A. Shelford, C. B. Tucker, D. M. Weary, and M. A. G. von Keyserlingk. 2004. Bacterial populations on teat ends of dairy cows housed in free stalls and bedded with either sand or sawdust. J. Dairy Sci. 87:1694-1701. https://doi.org/10.3168/jds.S0022 -0302(04)73322-6.

Zehner, M. M., R. J. Farnsworth, R. D. Appleman, K. Larntz, and J. A. Springer. 1986. Growth of environmental mastitis pathogens in various bedding material. J. Dairy Sci. 69:1932-1941. https://doi.org/ 10.3168/jds.S0022-0302(86)80620-8. 